\title{
The effect of experiential value, perceived quality and customer satisfaction on customer lifetime value: An example using Star Cruises
}

\author{
Ming-Cheng Lai, Feng-Sha Chou \\ (Graduate Institute of Business Administration, National Taipei College of Business, Taipei 100, Taiwan)
}

\begin{abstract}
The current study represents an attempt at experiential value, perceived quality and customer satisfaction influence on customer lifetime value. The sampling frame consisted of Star Cruises purchases in Taiwan. The authors have collected yield 268 questionnaires, by screening out 13 questionnaires, including those missing value or incomplete answer, and finally a usable sample of 255 questionnaires were utilized in this study. The results show that experiential value, perceived quality and customer satisfaction have positive effects to customer lifetime value. Especially, experiential value has the strongest direct effect. Therefore, if resources are limited, the manager should focus on shaping the experiential value to increase customer lifetime value. Implications for marketing theory and practitioners are discussed, and possible directions for future research are sketched.
\end{abstract}

Key words: experiential value; perceived quality; customer satisfaction; Star Cruises; customer lifetime value

\section{Introduction}

In what has been dubbed an emerging "Experience Economy", experiential value has been defined as "perceptions are based upon interactions involving either direct usage or distanced appreciation of goods and services". These interactions provide the basis for the relativistic preferences held by the individuals involved (Holbrook \& Corfman, 1985). Experiential value included both extrinsic and intrinsic benefit (Babin \& Darden, 1995; Mano \& Oliver, 1993). Although most empirical examinations of experiential value impact on satisfaction, and verified with regard to experiences with Internet shopping (Mathwick, et al., 2001). However, this study in Taiwan cruises industry, the extent to which customer satisfaction's impact of experiential value on consumer lifetime value is unconfirmed.

Corporation's value based on customer perceived quality. Firms provide differentiate product or services that enhance customer subjective satisfaction. Customer perceived quality will impact degree of customer satisfaction.

Accordingly, the purposes of this study is as follows: (1) to investigate the relationship between experiential value and perceived quality and customer satisfaction in cruises industry, (2) to explore the relationships between experiential value, perceived quality and customer lifetime value and (3) to understand the relationship between customer satisfaction and customer lifetime value.

Ming-Cheng Lai, associate professor, Graduate Institute of Business Administration, National Taipei College of Business; research fields: marketing, human resources management, organizational behavior.

Feng-Sha Chou, graduate student, Graduate Institute of Business Administration, National Taipei College of Business; research field: marketing. 


\section{Conceptual framework and the model}

The conceptual model is shown in Fig. 1.

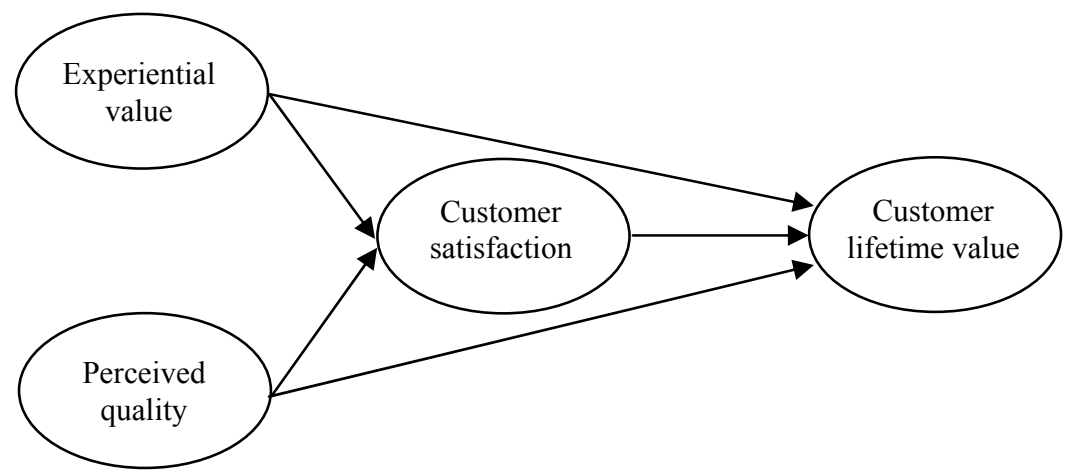

Fig. 1 Conceptual model

The model in Fig. 1 provides a pictorial representation about how selected customer lifetime value might affect experiential value and perceived quality, as discussed below.

The model proposes that experiential value and customers' quality perceptions are positive related to customer satisfaction. The proposition was deducted logically from the following research finding (Kwei \& Ming, 2007; Chwo, Lei, Yu \& Hsing, 2005; Shank, 2002; Ruth, 1998): First, experiential value and perceived quality have a direct positive effect on customer lifetime value; Second, customer satisfaction are positively associated with customer lifetime value; Third, experiential value, perceived quality and customer lifetime value have been shown to be theoretically and empirically distinct concepts, able to exist uniquely yet simultaneously. Taken together, these finding lead to the following questions: Do experiential value and perceived quality have direct effect on customer satisfaction? Do experiential value and perceived quality affect both customer satisfaction and lifetime value simultaneously? Does customer satisfaction have direct effect on customer lifetime value?

Customer satisfaction studies in the marketing literature are influenced by several factors. In the field of cruise passengers, Petric (2004) provided evidence that passengers' satisfaction is explained by value and quality. Previous research have investigated the relationships between quality satisfaction and behavior intentions. They provided the evidence that the quality of the opportunity has a direct effect on behavioral intentions, in addition to an indirect effect via satisfaction (quality of experience). Behavioral intentions are explained by both quality and satisfaction, which in turn explain loyalty and willingness to pay more (customer lifetime value) (Carlos \& António, 2008). Previous theories suggest that customer satisfaction mediates the relationship between customer's quality perceptions and firm outcome (Oliver, 1997; Oliver, 1999). Wu and Liang (2009) found restaurant environment factors and interactions with other consumers indirectly and positively influence consumer satisfaction through experiential value. The distinction is important because each component might be provided by a different marketing entity.

\section{Hypothesis development}

The following hypothesis is therefore presented based on previous research and these observations.

Experiential value, customer satisfaction and customer lifetime value:

H1: Experiential value has positive effect on customer satisfaction.

$\mathrm{H} 2$ : Experiential value has positive effect on customer lifetime value. 
Perceived quality, customer satisfaction and customer lifetime value:

H3: Perceived quality has positive effect on customer satisfaction.

H4: Perceived quality has positive effect on customer lifetime value.

Customer satisfaction and customer lifetime value:

H5: Customer satisfaction has positive effect on customer lifetime value.

\section{Method}

\subsection{Research context of Star Cruises purchases}

The purchase of Star Cruises is an appropriate context for the study of experiential value and perceived quality because it provides several desired characteristics: First, more people in Taiwan are more attach importance to leisure activity, and one of famous leisure activity is Star Cruises. Second, Star Cruises is the third largest cruise operator in the world, is a global cruise brand and the largest cruise operator in Aisa-Pacific.

\subsection{Sample characteristics}

Among the total amount of 268 copies returned, 13 copies were either with omission or incomplete answer, a usable sample of 255 questionnaires was utilized in this study. About $59.8 \%$ is female; $25.7 \%$ are $21-29$ years old; and $22.1 \%$ are $30-39$ years old; $29.5 \%$ have senior high school degree; $28.7 \%$ have a college degree; $77 \%$ live in northern Taiwan.

\section{Result}

\subsection{Scale reliabilities and validity}

The Cronbach's $\alpha$ coefficients indicate the internal consistency reliability. With regard to minimum acceptable criterion, Nunnally (1978) suggested that Cronbach's $\alpha$ a coefficient greater than 0.7 is high reliability while less than 0.35 is low reliability, which should be rejected. Table 1 summarized the result of internal consistency reliability as follows. From Table 1, the reliability of each of the four multi-item reflective scales exceeded 0.88 that would mean that the internal consistency reliability is high. In addition, the authors assess the reliability jointly for all items of a construct by computing the composite reliability (CR). From Table 1, composite reliability value for each construct was 0.88 or more and reveals an acceptable fit to the data. It exhibits that this study possesses the better composite reliability.

Table 1 Scale reliabilities and validity

\begin{tabular}{llllllll}
\hline Variables & No. of items & Factor loading & Cronbach's $\alpha$ & Eigenvalue & $\begin{array}{l}\text { Explained } \\
\text { variance }\end{array}$ & $\begin{array}{l}\text { Composite } \\
\text { reliability }\end{array}$ & AVE \\
\hline Experiential value & 6 & $0.68-0.93$ & 0.933 & 4.512 & 0.752 & 0.933 & 0.701 \\
Perceived quality & 4 & $0.73-0.92$ & 0.881 & 2.969 & 0.742 & 0.887 & 0.664 \\
Customer satisfaction & 4 & $0.76-0.94$ & 0.924 & 3.274 & 0.819 & 0.926 & 0.759 \\
Customer lifetime value & 5 & $0.84-0.96$ & 0.963 & 4.354 & 0.871 & 0.963 & 0.917 \\
\hline
\end{tabular}

Validity is that the measurable implement is whether up accurately examine the level of items, which researchers want to measure. Factor analysis showed that the items loaded on a single factor, which provides proof of unidimensionality. This study computes that average variance extracted (AVE) to confirm the discriminant validity. In Table 1, the AVE exceeded 0.664, meaning the questionnaire used in this study performs converged validity. In addition, AVE can be used to evaluate discriminant validity. Table 2 shows the descriptive 
The effect of experiential value, perceived quality and customer satisfaction on customer lifetime value: An example using Star Cruises

statistics and correlations between the construct.

Furthermore, in this study, the authors acquire factor loading in all constructs are all higher than 0.7 which means the overall questionnaire quality is good and has a better construct validity.

Table 2 Analysis of discriminate validity (SEM correlations ${ }^{\mathrm{a}}$ )

\begin{tabular}{|c|c|c|c|c|}
\hline Variables & Experiential value & Perceived quality & Customer satisfaction & Customer lifetime value \\
\hline Experiential value & $0.701^{\mathrm{b}}$ & & & \\
\hline Perceived quality & 0.921 & 0.664 & & \\
\hline Customer satisfaction & 0.842 & 0.810 & 0.759 & \\
\hline Customer lifetime value & 0.897 & 0.895 & 0.808 & 0.917 \\
\hline
\end{tabular}

This study estimated the fit indexes indicate that the measurement model produces adequate fit to the data by confirmatory factor analysis (CFA), the result are summarized in Table 3.

Table 3 Fit indexes of constructs

\begin{tabular}{|c|c|c|c|c|c|}
\hline Fit Indexes & Threshold & $\begin{array}{l}\text { Experiential } \\
\text { value }\end{array}$ & $\begin{array}{l}\text { Perceived } \\
\text { quality }\end{array}$ & $\begin{array}{l}\text { Customer } \\
\text { satisfaction }\end{array}$ & $\begin{array}{l}\text { Customer } \\
\text { lifetime value }\end{array}$ \\
\hline RMSEA & $\begin{array}{l}\leqq 0.05,0.05-0.08 \\
\text { (McDonald \& Ho, 2002) }\end{array}$ & 0.208 & 0.091 & 0.189 & 0.148 \\
\hline CFI & $\begin{array}{l}\geqq 0.90 \\
\text { (Bentler,1995) }\end{array}$ & 0.950 & 0.990 & 0.980 & 0.980 \\
\hline GFI & $\begin{array}{l}\geqq 0.90 \\
(\text { Bagozzi \& Yi,1988) }\end{array}$ & 0.870 & 0.990 & 0.960 & 0.950 \\
\hline AGFI & $\begin{array}{l}\geqq 0.80 \\
(\text { Sharma,1996) }\end{array}$ & 0.710 & 0.940 & 0.810 & 0.850 \\
\hline RMR & $\begin{array}{l}\leqq 0.05 \\
\text { (Joreskog.\& Sorbom, 1993) }\end{array}$ & 0.071 & 0.026 & 0.028 & 0.016 \\
\hline SRMR & $\begin{array}{l}\leqq 0.08 \\
(\text { Hu \& Bentler, 1999) }\end{array}$ & 0.047 & 0.018 & 0.026 & 0.013 \\
\hline
\end{tabular}

\subsection{Model assessment and tests of hypothesis}

The relationships hypothesized in Fig. 1 were tested using LISREL 8.54 with the sample covariance matrix as input. The results are summarized in Table 4. Model fit statistics in Table 5 collectively indicate that the proposed model fit the data relatively acceptable (The model is saturated, the fit is perfect!).

Among all the hypothesized paths run by LISREL, this study found the following outcomes in Table 4, that: (1) EV and PQ have significant positive effect on CS. (2) EV and PQ influences significantly, which is distinguished from the discussion in literature CLV. (3) Experiential value is the most important factor to influence customer satisfaction.

Table 4 Measurement model results for theoretical model

\begin{tabular}{lll}
\hline & \multicolumn{2}{c}{ Theoretical model } \\
\cline { 2 - 3 } & Parameter estimates & $t$-value \\
\hline $\mathrm{H} 1: \mathrm{EV} \rightarrow \mathrm{CS}$ & 0.55 & $6.90^{*}$ \\
$\mathrm{H} 2: \mathrm{EV} \rightarrow \mathrm{CLV}$ & 0.39 & $5.23^{*}$ \\
$\mathrm{H} 3: \mathrm{PQ} \rightarrow \mathrm{CS}$ & 0.20 & $2.48^{*}$ \\
$\mathrm{H} 4: \mathrm{PQ} \rightarrow \mathrm{CLV}$ & 0.44 & $6.08^{*}$ \\
$\mathrm{H} 5: \mathrm{CS} \rightarrow \mathrm{CLV}$ & 0.15 & $2.60^{*}$ \\
Fit statistics & The model is saturated, the fit is perfect! \\
\hline
\end{tabular}

Notes: $E V=$ Experiential value; $P Q=$ Perceived quality; $C S=$ Customer satisfaction; $C L V=$ Customer lifetime value; $* p<0.05$. 
The effect of experiential value, perceived quality and customer satisfaction on customer lifetime value: An example using Star Cruises

Table 5 shows the direct and indirect effect in the theoretical model. Examining along with Table 5, the authors find that CS may mediate the relationships between EV and CLV. The indirect effect of EV on CLV is $0.08(t$-value $=2.43)$. But, PQ not significant indirect impact on CLV (path coefficient $=0.03, t$-value $=1.79)$.

Table 5 The direct and indirect effect of modified model

\begin{tabular}{|c|c|c|c|c|c|}
\hline & & \multicolumn{2}{|c|}{ Customer satisfaction } & \multicolumn{2}{|c|}{ Customer lifetime value } \\
\hline & & Path & $t$-value & Path & $t$-value \\
\hline \multirow[t]{3}{*}{ Experiential value } & Direct & 0.55 & $6.90 *$ & 0.39 & $5.23 *$ \\
\hline & Indirect & - & - & 0.08 & $2.43 *$ \\
\hline & Total & 0.55 & $6.90^{*}$ & 0.47 & $6.86^{*}$ \\
\hline \multirow[t]{3}{*}{ Perceived quality } & Direct & 0.20 & $2.48^{*}$ & 0.44 & $6.08^{*}$ \\
\hline & Indirect & - & - & 0.03 & 1.79 \\
\hline & Total & 0.20 & $2.48^{*}$ & 0.47 & $6.50 *$ \\
\hline \multirow[t]{3}{*}{ Customer satisfaction } & Direct & - & - & 0.15 & $2.60^{*}$ \\
\hline & Indirect & - & - & - & - \\
\hline & Total & - & - & 0.15 & $2.60 *$ \\
\hline
\end{tabular}

\section{Discussion and implication}

The goal of this research is to examine how experiential value and perceived quality affect customer satisfaction and customer lifetime value. A major result is that experiential value and perceived quality are positively related to both customer satisfaction and customer lifetime value simultaneously, provides future evidence that cruise passengers' satisfaction are continuously influenced by customer's experiential value and perceived quality. In other words, the cruise firms have to establish good impression about high perceived quality and experiential value, then might achieve high customer satisfaction and customer lifetime value.

The finding suggests that firm should focus on constructing customer perceived quality and intensify quality. Through customer perceived quality to influence buying intention, thus increasing loyalty to achieve high customer lifetime value. Finally, if firm can use the act of experiential value freely, that would let customer perceived more satisfaction.

As buyer decision process becomes a more popular topic with both researches and managers, increased attention must be paid to its multiple conceptualizations and measurement strategies. Only when these issues have been attended to can researchers draw convincing concerning the consequences of experiential value and perceived quality for customer satisfaction and customer lifetime value. Many of the questions raised in this paper can only be answered by further empirical research. Future research could expand upon the current findings by examining the role played by possible experiential media such as oral and visual identity.

\section{References:}

Babin, B. J., William, R. D. \& Griffin, M.. (1994). Work and/or fun: Measuring hedonic and utilitarian shopping value. Journal of Consumer Research, 20(March), 644-656.

Bolton, R. N.. (1998). A dynamic model of the duration of the customer's relationship with a continuous service provider: The role of satisfaction. Marketing Science, 17(1), 45-66.

Carlos, M. S., Ramalho, C. \& Silvestre, A. L.. (2008). Satisfaction and behavioural intentions of cruise passengers visiting the Azroes. Tourism Economics, 14(1), 169-184.

Holbrook, M. B. \& Corfman, K. P.. (1985). Quality and value in the consumption experience: Phaedrus rides again. In: Jacob, J. \& Jerry, C. O. (Eds.), Perceived quality: How consumers view stores and merchandise. Lexington, MA: Lexington Books, 31-57. 
The effect of experiential value, perceived quality and customer satisfaction on customer lifetime value: An example using Star Cruises

Mano, H. \& Oliver, R. L.. (1993). Assessing the dimensionality and structure of the consumption experience: Evaluation, feeling and satisfaction. Journal of Consumer Research, 20, 451-466.

Mathwick, C., Malhotra, N. \& Rigdon, E.. (2001). Experiential value: Conceptualization, measurement and application in the catalog and Internet shopping environment. Journal of Retailing, 77, 39-56.

Nunnally, J. C.. (1978). Psychometric theory. New York: McGraw-Hill, Inc.

Oliver, R. L.. (1997). Satisfaction: A behavioural perspective on the customer. Boston, MA: Irwin/McGraw-Hill.

Oliver, R. L.. (1999). Whence consumer loyalty? Journal of Marketing, 63(4), 33-44.

Petrick, J. F.. (2004). The roles of quality, value, and satisfaction in predicting cruise passengers' behavioural intentions. Journal of Travel Research, 397-407.

Shank, L. P.. (2002). Customer's perceptions of quality,value and satisfaction: A behavioral consequences view. D.B.A., Nova Southeastern University

Shieh, K. F. \& Cheng, M. S.. (2007). An empirical study of experiential value and lifestyles and their effects on satisfaction in adolescents: An example using online gaming. Academic Research Library, 42(Spring), 199-215.

Wu, C. H. J. \& Liang, R. D.. (2009). Effect of experiential value on customer satisfaction with service encounters in luxury-hotel restaurants. International Journal of Hospitality Management, 28(4), 586-593.

Yu, C. J., Wu, L. Y., Chiao, Y. C. \& Tai, H. S.. (2005). Perceived quality, customer satisfaction, and customer loyalty: The case of lexus in Taiwan. Total Quality Management \& Business Excellence, 16(6), 707.

(Edited by Ruby and Chris) 